\title{
TEVAR for Uncomplicated Acute Type B Aortic Dissection: What is Success?
}

\section{Ganesh S Kumpati*}

Division of Cardiothoracic Surgery, University of Utah, UT 84132, USA

Type B aortic dissection (typically beginning just distal to the left subclavian artery with variable distal propagation) is a commonly identified clinical problem. Acute type B aortic dissection (less than 14 days from onset) is divided into two types: complicated and uncomplicated. For complicated dissections (visceral malperfusion, aortic rupture, symptoms despite maximal medical therapy), endovascular repair has represented a significant advance over open repair options, and represents a major treatment advance [1] for this difficult problem. Following intervention for complicated aortic dissection, there is positive remodeling of the remaining dissected aorta [2].

Although medical therapy has good short term outcome for uncomplicated type B aortic dissection, long term outcome with medical therapy is not good [3]. Late aorta-related morbidity and mortality is related to progressive aneurysmal dilation of the false lumen with late aortic rupture. Once established aneurysmal dilation of the false lumen has occurred, treatment options become difficult, ranging from endovascular intervention with lower morbidity but variable outcome to open surgery with higher morbidity but excellent long term outcome. Thus, the ideal endovascular intervention would eliminate the aortic dissection early enough in the course of the disease to eliminate late aneurysm complications before an open procedure would be necessary.

The INSTEAD trial has attempted to answer this question. At 2 year follow up, the morbidity for the treatment arm (endovascular repair) versus medical therapy were similar [4]. The treatment arm had more patients with stabilization/regression of the false lumen flow. Long term follow up is necessary to see if this reduces aneurysm formation.

The finding that endovascular intervention did not reduce mortality at 2 years as compared to medical therapy is not a surprise. The real issue is whether late mortality from aortic events is reduced by early intervention. The ability to perform minimally invasive intervention to prevent a later major procedure is quite appealing. This represents the future of treatment for thoracic aortic disease.

\section{References}

1. Fattori R, Tsai TT, Myrmel T, Evangelista A, Cooper JV, et al. (2008) Complicated acute type $B$ dissection: is surgery still the best option?: a report from the International Registry of Acute Aortic Dissection. JACC Cardiovasc Interv 1: 395-402.

2. Conrad MF, Crawford RS, Kwolek CJ, Brewster DC, Brady TJ, et al. (2009) Aortic remodeling after endovascular repair of acute complicated type B aortic dissection. J Vasc Surg 50: 510-517.

3. Tsai TT, Fattori R, Trimarchi S, Isselbacher E, Myrmel T, et al. (2006) Long-term survival in patients presenting with type $B$ acute aortic dissection: insights from the International Registry of Acute Aortic Dissection. Circulation 114: 22262231.

4. Nienaber CA, Rousseau H, Eggebrecht H, Kische S, Fattori R, et al. (2009) Randomized comparison of strategies for type B aortic dissection: the INvestigation of STEnt Grafts in Aortic Dissection (INSTEAD) trial. Circulation 120: $2519-2528$.
*Corresponding author: Ganesh S Kumpati, MD, Division of Cardiothoracic Surgery, University of Utah, 30 N. 1900 E., \#3C-127, Salt Lake City, UT 84132 USA, Tel: (801) 581-5311; Fax: (801) 585-3936; E-mail: Ganesh.Kumpati@hsc.utah.edu

Received May 16, 2013; Accepted May 18, 2013; Published May 20, 2013 Citation: Kumpati GS (2013) TEVAR for Uncomplicated Acute Type B Aortic Dissection: What is Success? J Vasc Med Surg 1: e105. doi: 10.4172/23296925.1000e105

Copyright: (c) 2013 Kumpati GS. This is an open-access article distributed under the terms of the Creative Commons Attribution License, which permits unrestricted use, distribution, and reproduction in any medium, provided the original author and source are credited. 